\title{
Reviewing Relationship between Financial Structure and Firms Performance in Firms Traded on the Tehran Stock Exchange
}

\author{
Mojtaba Akbarpour (Corresponding author) \\ University of Sistan and Bluchestan \\ Zahedan, Iran \\ E-mail: alber.camus@yahoo.com \\ Shahoo Aghabeygzadeh \\ University of Sistan and Bluchestan \\ Zahedan, Iran \\ E-mail: beghzadehshaho@yahoo.com
}

Received: June 11, $2011 \quad$ Accepted: July 14, $2011 \quad$ Published: November 21, 2011

doi:10.5430/ijba.v2n4p175

URL: http://dx.doi.org/10.5430/ ijba.v2n4p175

\begin{abstract}
:
In this paper we have investigated the relationship between financial structure and accounting measurement for evaluating performance (ROA, ROE) in listed firms of Tehran exchange in 2005-2010. Due to some constraints, 101 firms were chosen as research sample. Then, data was collected by library research and Rahavard Novin software and calculation has done for examining 3 financial structures and 2 accounting measurement for evaluating performance. Multiple regression and $\mathrm{T}$ and $\mathrm{F}$ statistics were used to test the research. Results indicate that there is a significant relationship between financial structure and ROA, but there isn't such a significant relationship between financial structure and ROE.
\end{abstract}

Keywords: Financial Structures, Return of Assets Ratio (ROA), Return of Equity Ratio (ROE)

\section{Introduction}

Assets can be fixed or current, tangible or intangible; and debts also can be short term or long term, fixed or floating, risk free or risky. In an ideal situation, assets and debts should be well-adjusted (Hussy, 1999)

Evaluation and performance measurement are among the most debated and discussed issues in financial management. The goal of financial management is to use and allocate capital in a proper way in order to create maximum value for both stockholder and profit company owners. There are many different views explaining and extending these concepts in financial management. The first group of such viewpoints comprises accounting models that obtain a firm's value by multiplying firm's profit to conversion coefficients with the value of (P/E ratio). The second group comprises economic models that determine a firm's stock value on the basis of its earning power ,potential investment and difference of return rate and capital costs (Jahankhani and Zarifard,1995).

Maximizing a firm's value requires implementing profitable projects. In modern world, because of the competitive nature of the market, determining methods of proper finance for increasing profitability and company survival is a vital issue. Due to ownership distance from management, we need extended finance and also attracting the influx of fund owners toward the use of their own funds for increasing wealth, analyzing firm performance and financial structure, until a proper investment level is achieved (Nikbakht \& Peykani, 2010)

In terms of financing sources, firms are divided into two categories according to their financing policy: (1) internal financial funds (2) external financial funds. In internal funds, companies use gained profit for financing. It means that instead of dividends distribution, they use profit for the company's operation in order to have higher return. In contrast, external financing companies use debt and also issue securities (Titman \& Grinblatt, 1998). 
A process which leads to final decision is called financial structure determining methods. Methods of determining financial structure should be chosen with particular attention to the main features of securities influenced by internal factors within the firm or other external factors (Esfahani, 2006).

Financial managers choose policies related to the financial structure of firms for increasing stockholders' wealth; they also consider solutions such as debtor equity increase for financing their projects (Asghari, et al., 2009).

The aim of determining financial structure is to distinguish structure of financial fund in order to maximize shareholders' wealth. We can consider financial structure as an effective factor on shareholders wealth. The more bonds a firm issues, the higher will be its breakeven point and leverage. Otherwise, the profit per share will decline; therefore, financial managers measure different impacts of different financial structures on shareholders' wealth (Peynor, 2000).

\section{Research Objectives}

The aim of this paper is to examine important theories of financial management in the field, which in fact will be carried out through evaluating the relationship between financial structures and profitability measures of listed firms in Tehran Security Exchange. From the perspective of financial management, Capital consists of debt and equity. The fundamental difference between the two part of capital such as priority in offset, tax inclusion, fixed or unfixed earning rate and ...., similarity and joint point of liability and equity is that both of them use external financial resources. That is, equity uses which method for increasing or decreasing their capital, leads to searching for proper combinations of debt and equity. So that they can have tax advantages and at the other side can control their bankruptcy costs. This is not achievable unless through measuring and researching about obtaining an optimal ratio for each and every component of financial structure. In addition, this issue varies on the basis of the type of industry and the influence of external factors. In fact, this issue constitutes the overall framework of this study.

\section{Literature Review}

\subsection{Research Done Around the World}

Miller and Modigliani (1958) suggest that under the specific assumption that the existence of complete competitive marketplace, no income tax, no break down costs, lack of agency costs and asymmetry among market participant and replacing internal financing resources with external financing resources, managers cannot change the firm value just because of change in financing resource combinations. In other words, firm value is different from its capital structure.

Lara and Mesquita (2003) use multiple regression models to examine the relationship between capital structure and firms profitability in Brazil and conclude that: considering independent variables used in their study that include coefficients of short term debt and long term debt and also equity, results shows that there is a direct relation between profitability and short term debt and also equity and indirect relation of it with long term debt. They indicate high interest rate and volatility policy for the country and believed that this position leads to uncertainty of local industry and can't take managerial decision timely and also avoid using advanced policy in debt.

Ralf Elsas and David Florysiak (2008) write this paper with the aim of evaluating and summarizing capital structure in German firms and indicate that even with the passing of 50 years from primary study of Lara and Mesquita yet choosing optimal and ideal capital structure isn't possible and is the main challenge of researchers. In this study equity is as a positive and effective factor on capital structure and long term debt shows the reverse position.

Vishnu and Nageswara (2007) show that according to empirical evidence there is a relationship between industrial pricing and type of industry with capital structure and firms performance is in relation with debt ratios of firm. Comparing method of evaluating firm performance was equal with industry average in which firms was active and results of this paper also support of reducing avoidable hypothesis cost at emergency time.

Zeitun and Tian (2007) review the relationship between capital structure and firms performance with the information of 167 Jordan's firm in 1985-2003 and found that there is a significant relationship between short run debt ratio to total assets, total debt to total equity with return of assets.

Fosberg and Ghosh (2006) have done a research on U.S security exchange and New York security exchange. As companies in New York exchange used debt 5 to8 percent more than other companies in their financial structure, it proved that relationship between capital structure and ROA in New York security exchange is negative.

\subsection{Research Done in Iran}

Namazi and Shirzadeh (2004) in their research examined effect of capital on firm's profitability in Tehran security exchange in different industries. Research sample include 108 listed firms from different industries. That information related to ratio mean to assets and equity in a 5 year period was centralized and tested. And also information about debt 
ratio mean to assets and return of assets (ROA) collected and tested for that prior. In order to test hypothesis regression and correlated coefficient were used results of the tests indicate that generally there is positive relation between capital structure and profitability. But this relationship is so weak from the statistical point of view, because relationship between capital structure and profitability also depends on industry and optimal structure of capital is determined in different industry.

Naser Esfahani (2006), in his research suggested that market added value is one the economic measures of firms evaluation and performance measurement. This research is done in firms and industries that recently attract main part of financial funds in 1999-2005.hypothesis testes shows that capital structure and there Setting is effective on market added value of the studied. Firms

Framarzi Khosrovshahi (2007) examines relationship between capital structure and firms profitability, in this research ROA is as dependent variable and also 3 variables as independent variable. Research shows a relationship between capital structure and profitability but this relation is so weak.

Asghari and et al (2009) evaluate relationship between financial structure with firms profitability, with comparability approaches between strategic and non strategic industries. ROA was chosen as dependent variable and 3 variables as independent variable. Research result shows that relationship between financial structure and firm's profitability and also between strategic industries and this difference is so weak.

\section{Sample}

We choose our sample randomly and it is assumed that $\mathrm{p}=.5$ and $\mathrm{q}=.5$ with confidence level 0/95.

\subsection{Research Sample}

We have chosen firms that:

a- Continues were active in 2005-2010 in Tehran stock exchange and their financial information were accessible.

b- Financial period of firms ends to Esfand (Note 1) of each year. (These conditions avoid the effect of seasonal and other factor on research result and comparability increase.

c- Firms that didn't change their financial period in research period so that information will be for a twelve month period and comparability will be increased.

d- Equity of the firm should positive (we eliminate firms with negative equity)

e- Investment firms were eliminated because of different return calculation.

\subsection{Research Method}

This research tries to examine the influence of financial structure on firm's profitability so it used quasi- experimental applications.

\subsection{Variables}

Variables a concept that more than two value or figure is attributed to it in other words variables are features that can be observed or measured and also replace it with several figures classifies into two groups according to the roles that they play in research:

A: independent variable

B: dependent variable

In this research we consider 3 independent variables:

I-current liability ratio to total liability

II-equity ratio to total liability

III-non- current liability ratios to equity

And also dependent variables are as follows:

I. Return of assets (ROA)

II. Return of equity (ROE)

\section{Research Hypothesis Test}

First hypothesis of the research evaluate relationship between financial structure and return of assets (ROA) (as index of profitability). In order to test the hypothesis, zero and first hypothesis is defined as: 
$\mathrm{H}_{0}=$ there isn't any significant relationship between financial structure and return of assets.

$\mathrm{H}_{1}=$ there is significant relationship between financial structure and return of assets.

1-1: there is significant relation between current liabilities ratio to total liabilities and return of assets (ROA) in listed firms of Tehran security exchange.

1-2: there is significant relation between non-current liabilities ratio to equity and return of assets in listed firms in Tehran security exchange.

1-3: there is significant relation between equity ratio to total liabilities ratio to equity and return of assets in listed firms in Tehran security exchange.

First statistic credibility of regression is measured by F coefficients (Table 1). Coefficient equals 3.876 that according to this figure, It's significance equals 0.009 and because 0.009 is less that 0.05 so hypothesis is rejected and $\mathrm{H}_{1}$ is confirmed in next step we measure every independent variables relation with dependent variable significant level of this variables which are $0.051,0.08$ and 0.534 respectively (Table 2) because the two first variables are less so their relationship with return of assets is accepted but the third variable significant is rejected.

First ratio (FR): current liability to total liability, second ratio (SR): equity to total liability, third ratio (TR): non-current liability to equity.

$<$ Table 1 about here $>$

$<$ Table 2 about here $>$

$Y=7 / 657 F R, 1 / 213 S R$

Return of assets $=7.657$ (current liability ratio to total liability) +1.213 (equity ratio to total liability)

In table 3, it is shown that relationship between financial structure and ROA is 0.022 .

$<$ Table 3 about here $>$

Second hypothesis:

Second hypothesis examines relationship between financial structure and return of equity (as a profitability index) in listed firms of Tehran security Exchange. In order to test this hypothesis, first and zero hypothesis is defined as:

$\mathrm{H} 0=$ There isn't significant relationship between financial structure and return of equity in.

H1= There isn’t significant relationship between financial structure and return of equity in.

2-1: there is significant relationship between current liability ratios to total liability with return of equity in listed firms in Tehran security exchange.

2-2: there is significant relationship between non -current liability ratio to equity in listed firms in Tehran security exchange.

2-3: there is significant relationship between equity to total liability ratio to equity in listed firms in Tehran security exchange.

Obtained F from analyzing this hypothesis is 0.544 and significant level is 0.653 and because it is more than 0.05 , zero hypothesis (lake of any significant relationship) is accepted because main hypothesis rejected be rejected and their relationship between return of equity will be meaningless (Table 4).

Coefficient tables also show this take of relation. Significance of coefficient equals $0.252,0.599$, and 0.927 and because they are bigger than 0.05 so zero hypothesis is accepted that means lake of relationship with ROE.

$<$ Table 4 about here $>$

\section{Conclusion}

According to the results reached in the test of hypothesis direct relationship between variables indicating financial structure of assets (ROA) as a profitability index is confirms. So H0 which shows lake of relation is rejected and H1 hypothesis is accepted.

But existence of direct relationship between variables which show financial structure of firms and return of equity as profitability index isn't confirmed.

Financial performance is a measure in firm to reach shareholders financial goal to gain wealth. 
According to capital costs and its influence on firms value we can suggest that financial structure decisions are one of the important decisions of financial managers there is external research with different models about financial structure which are different from internal research. That reasons of this difference in results from economic sanctions, economic governance, market development failing and also because our country is a developing country. This with more research about external research and reexamining them and make change in critical external models. In Iran capital market we can get effective models in financing.

So according to result of this paper and past research results we recommend that:

1. Users in their analysis should pay more attention to internal effective factors on financial structure such has political factor, economic sanctions.

2. Risk aversions of manager also can be important factor in financial structure because risk aversion leads to no debt and using long term credits and this issues declines performance.

3. According to this research results there is significant relationship between financial structure and ROA that user can use it as internal or external factor in decision making.

\section{References}

Asghari \& et al, (2009). Evaluating Relationship Between Financial Structure With Firms Profitability,Journal of Bource,36-51

Faramarzi, K. F. (2007). Relationship Between Capital Structure \& Profitability, MS Thesis, Maz\&aran University

Fosberg, R. H. \& Ghosh, A. (2006). Profitability \& Capital Structure Of AMEX \& NYSE Firms, Journal of Business \& Economics Research, N11,p 57-64

Hussy, R (1999). Oxford dictionary For Accounting. 2ed edition, Oxford Publication

Jahankhani, A. \& Zarifard, A. (1995). Do Managers \& Shareholders Use Proper Measurement for Evaluating value? Financial research, vol.7, 8

Lara, J. E. \& Mesquita, J. (2003). Capital Structure \& Profitability; the Brazilian Case, Vancouver: academy of business \& administration sciences conference, julay 11-13

Modigiliani, F. \& Miller, M. (1958). The Cost Of Capital, Corporation Finance \& The Theory Of Investment, American economic review,261-297

Nageswara, R. \& Vishnus, R. (2007). Capital structure, industry pricing, \& firm performance, Proceeding of the $13^{\text {th }}$ Asia pacific management conference Melbourne, Australia, 2007,280-286

Namazi, M. \& Shirzadeh, J. (2005). Evaluating Relationship Between Capital Structure \& Profitability Of Ffirms In Tehran Stock Exchange, Accounting \& auditing Review,vol.42,75-95

Nasr, E. Y. (2006). Reviewing Relationship Between Capital Structure \& Economic value Added MS Thesis, Alame University

Nikbakht, M. R. \& Peykani, M. (2009). Reviewing Relationship Between Capital Structure \& Accounting Performance Measurement In Listed Firms Of Tehran Stock Exchange, Financial research,vol.28,89-104

Peynor, R. (1379). Financial Manangement,translated by:jahankhani,al,\& Parsaiyan Ali, vol.2,Samt publication, $6^{\text {th }}$ edition

Ralf, E. \& David, F. (2008). Empirical capital structure research: new ideas, recent evidence, \& methodological issues discussion paper 2008-10 Munich Schoo of Management University of Munichfakultat Fr betriebswirtschaft Ludwig Maximilians-universitat Munche

Tian, G. G. \& Zeitun, R. (2007). Capital Structure \& CorporatePerformance, Australasian Accounting Business \& Finance, $\mathrm{N}$ 4,P 40.

Titman, S. M. (1998). Financial markets \& corporate strategy, Mcgrow-Hill,Inc.

\section{Notes}

Note 1. .End of Esfand is approximately equals with 20 of March 
Table 1

\begin{tabular}{|l|l|l|l|l|l|}
\hline Model & Sum of Squares & df & Mean Square & F & Sig. \\
\hline Regression & 2376.261 & 3 & 792.087 & 3.876 & $.009^{\mathrm{a}}$ \\
Residual & 103409.641 & 506 & 204.367 & & \\
Total & 105785.902 & 509 & & & \\
\hline
\end{tabular}

a. Predictors: (Constant), FR, SR, TR

b. Dependent Variable: ROA

Table 2

\begin{tabular}{|c|c|c|c|c|c|}
\hline \multirow{2}{*}{ Model } & \multicolumn{2}{|l|}{ Unstandardized Coefficients } & $\begin{array}{c}\text { Standardized } \\
\text { Coefficients }\end{array}$ & & \\
\cline { 2 - 4 } Constant & 3.446 & 3.388 & & Sig. \\
FR & 7.657 & 3.917 & .086 & 1.955 & .051 \\
SR & 1.213 & .456 & .117 & 2.658 & .008 \\
TR & -.029 & .046 & -.027 & -.623 & .534 \\
\hline
\end{tabular}

a. Dependent Variable: ROA

b. Predictors: (Constant), FR, SR, TR

Table 3

\begin{tabular}{|c|c|c|c|c|}
\hline Model & $\mathrm{R}$ & $\mathrm{R}$ Square & Adjusted R Square & Std. Error of the Estimate \\
\hline 1 & $.150^{\mathrm{a}}$ & .022 & .017 & 14.2956944 \\
\hline
\end{tabular}

a. Predictors: (Constant), FR, SR, TR

Table 4

\begin{tabular}{|c|c|c|c|c|c|c|}
\hline \multicolumn{2}{|c|}{ Model } & Sum of Squares & $\mathrm{df}$ & Mean Square & $\mathrm{F}$ & Sig. \\
\hline 1 & Regression & .341 & 3 & .114 & .544 & $.653^{\mathrm{a}}$ \\
& Residual & 105.886 & 506 & .209 & & \\
\hline Total & 106.228 & 509 & & & \\
\hline
\end{tabular}

a. Predictors: (Constant), FR, SR, TR

b. Dependent Variable: $\quad$ ROE 